Supporting information

\title{
Multiplex Mass Spectrometry Analysis of Amyloid Proteins in Human Plasma for Alzheimer's Disease Diagnosis
}

Weimin $\mathrm{Ni}^{1}$, William Jagust ${ }^{2}$ and Daojing Wang ${ }^{1 *}$

1. Newomics Inc., Berkeley, CA 94710, USA.

2. School of Public Health and Helen Wills Neuroscience Institute, University of California at Berkeley, CA 94710, USA; Molecular Biophysics and Integrated Bioimaging, Lawrence Berkeley National Laboratory, Berkeley CA 94710, USA

*email: wang@newomics.com

\section{Table of Contents}

Figure S1: Mass spectra of full scan MS1 and targeted MS1 corresponding to Figure 1a

Figure S2: Log2 plotted data of targeted MS1 analysis of A $\beta$ proteins in plasma corresponding to Figure $2 \mathrm{~b}$ and $2 \mathrm{c}$

Figure S3: Plasma A $\beta$ proteins IP-MS assay reproducibility across multiple days

Figure S4: Relationship between $\mathrm{A} \beta 42 / \mathrm{A} \beta 40$ values and age, with different $A P O E \varepsilon 4$ status

Table S1: MS parameters for targeted MS1 analysis of A $\beta$ proteins

Table S2: Reproducibility analysis of IP-MS assay of plasma A $\beta$ proteins 

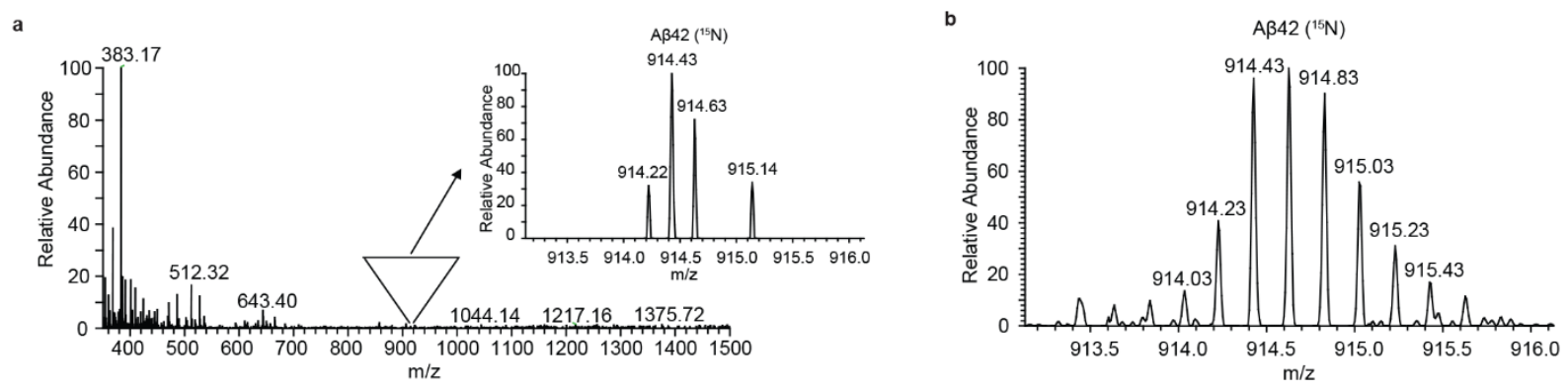

Supplemental Figure 1. Mass spectra of full scan MS1 and targeted MS1 corresponding to

Figure 1a. Shown here are the spectra at the apex of elution profile. a, Full scan MS1 analysis. Insert shows the zoom-in view of ${ }^{15} \mathrm{~N}$ A $\beta 42$ with missing isotopic peaks. $\mathbf{b}$, Targeted MS1 of ${ }^{15} \mathrm{~N}$ A $\beta 42$ showing all expected isotopic peaks. 

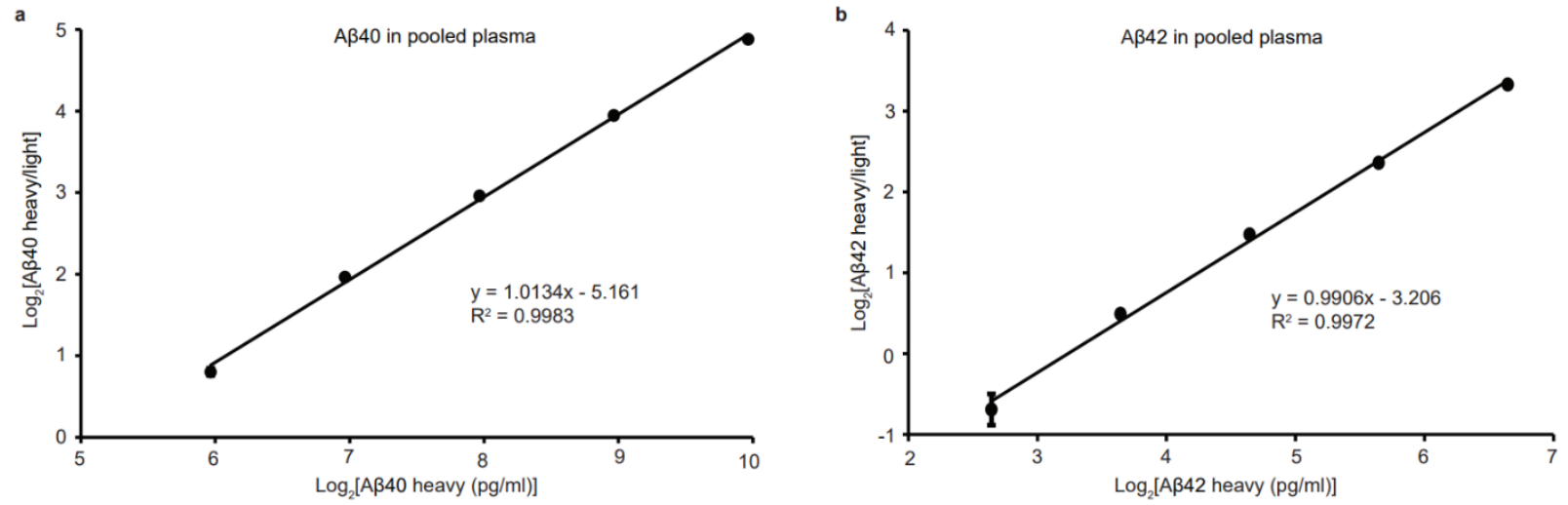

Supplemental Figure 2. Log2 plotted data of targeted MS1 analysis of A $\beta$ proteins in plasma corresponding to Figure 2b and 2c. a, $A \beta 40$ in pooled plasma. b, $A \beta 42$ in pooled plasma. Error bars represent standard errors of means. The slopes of the linear regression lines for both $A \beta 40$ and $\mathrm{A} \beta 42$ are close to 1. 

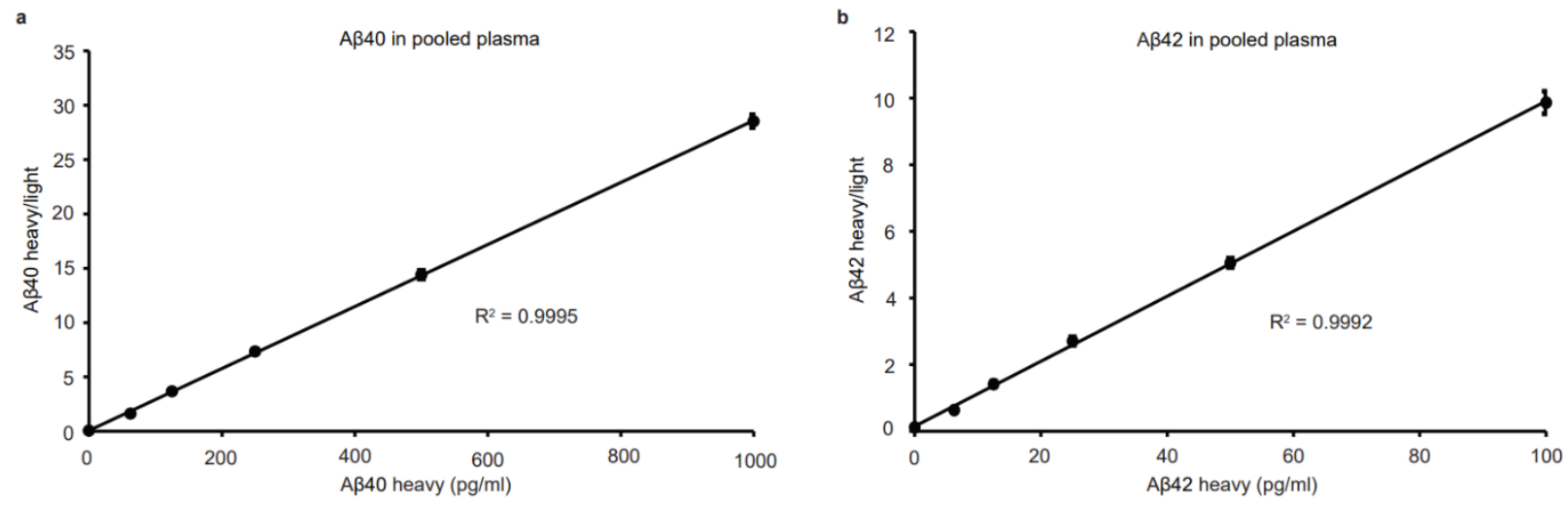

Supplemental Figure 3. Plasma Aß proteins IP-MS assay reproducibility across multiple days. Aliquots of the plasma $A \beta$ proteins IP samples used in Figure 2 were re-run on the same column after one week. $\mathbf{a}$ and $\mathbf{b}$, linear responses of the intensity ratio of heavy/light plot with the amount of heavy protein spiked into the pooled plasma for $A \beta 40$ and $A \beta 42$, respectively. Error bars represent stand errors of means from three repeated injections. Both $A \beta 40$ and $A \beta 42$ assays show excellent reproducibility. 


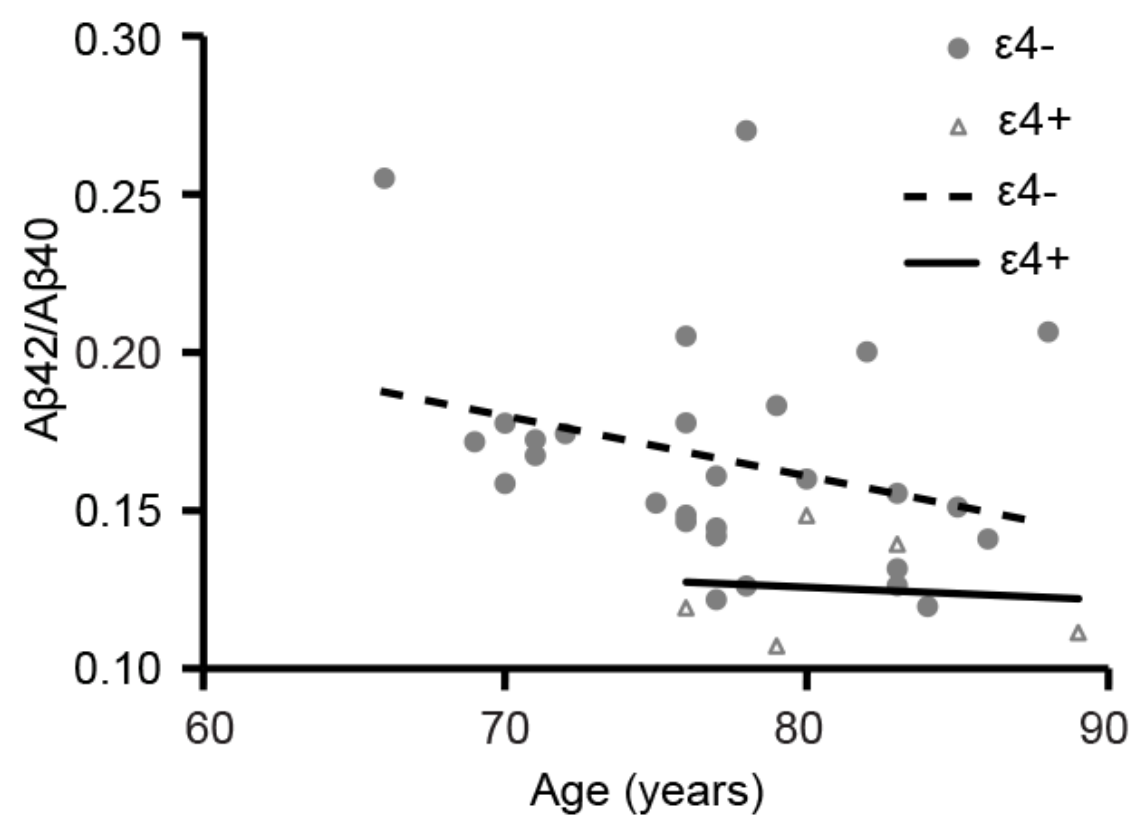

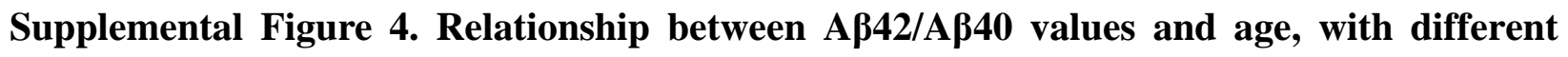
APOE $\varepsilon 4$ status. Plasma A $\beta 42 / A \beta 40$ was lower with older age (Spearman $\rho=-0.33, p=0.08$ ) and even lower in APOE $\varepsilon 4$ carriers. Three individuals have missing APOE $\varepsilon 4$ status. 
Supplemental Table 1: MS parameters for targeted MS1 analysis of A $\beta$ proteins

\begin{tabular}{|l|l|l|l|l|l|l|l|}
\hline Protein name & $\begin{array}{l}\text { Target } \\
\mathrm{m} / \mathrm{z}\end{array}$ & $\begin{array}{l}\text { Isolation } \mathrm{m} / \mathrm{z} \\
\text { range }\end{array}$ & $\begin{array}{l}\mathrm{CS} \\
{[\mathrm{z}]}\end{array}$ & $\begin{array}{l}\text { Start } \\
{[\mathrm{min}]}\end{array}$ & $\begin{array}{l}\text { End } \\
{[\mathrm{min}]}\end{array}$ & $\begin{array}{l}\text { Peak Retention } \\
\text { Time [min] }\end{array}$ & $\begin{array}{l}\text { Total MS } \\
\text { intensity (Area) }\end{array}$ \\
\hline $\mathrm{A} \beta 38$ & 827.21 & $825.71-828.71$ & 5 & 10 & 12.4 & 11.36 & 4291448 \\
\hline $\mathrm{A} \beta 38\left({ }^{13} \mathrm{C}\right)$ & 833.23 & $831.73-834.73$ & 5 & 10 & 12.4 & 11.36 & 18417822 \\
\hline APP669-711 & 938.48 & $936.98-939.98$ & 5 & 10 & 13.3 & 12.42 & 2478081 \\
\hline $\begin{array}{l}\text { APP669-711 } \\
\left({ }^{15} \mathrm{~N}\right)\end{array}$ & 949.84 & $948.34-951.34$ & 5 & 10 & 13.3 & 12.42 & 5282503 \\
\hline $\mathrm{A} \beta 40$ & 866.84 & $865.34-868.34$ & 5 & 10 & 18 & 13.07 & 28242844 \\
\hline $\mathrm{A} \beta 40\left({ }^{15} \mathrm{~N}\right)$ & 877.41 & $875.91-878.91$ & 5 & 10 & 18 & 13.03 & 45400860 \\
\hline $\mathrm{A} \beta 42$ & 903.66 & $902.16-905.16$ & 5 & 10 & 18 & 14.15 & 1159165 \\
\hline $\mathrm{A} \beta 42\left({ }^{15} \mathrm{~N}\right)$ & 914.63 & $913.13-916.13$ & 5 & 10 & 18 & 14.15 & 1288050 \\
\hline
\end{tabular}

The last two columns show the retention time at the peak apex, and the total MS intensity value summed up from the isotopomeric peak areas, using one of the plasma IP sample as an example.

Start [min]: MS scan start-time

End [min]: MS scan end-time

CS: charge state 
Supplemental Table 2: Reproducibility analysis of IP-MS assay of plasma A $\beta$ proteins

\begin{tabular}{|c|c|c|c|}
\hline Replicate & $\begin{array}{c}\mathrm{A} \beta 42 \\
(\mathrm{pg} / \mathrm{ml})\end{array}$ & $\begin{array}{c}\mathrm{A} \beta 40 \\
(\mathrm{pg} / \mathrm{ml})\end{array}$ & $\mathrm{A} \beta 42 / \mathrm{A} \beta 40$ \\
\hline 1 & 9.1 & 31.7 & 0.288 \\
\hline 2 & 9.1 & 32.4 & 0.281 \\
\hline 3 & 9.6 & 32.5 & 0.295 \\
\hline Mean & 9.3 & 32.2 & 0.288 \\
\hline SD & 0.29 & 0.44 & 0.007 \\
\hline CV (\%) & 3.1 & 1.4 & 2.4 \\
\hline
\end{tabular}

Pooled commercial human plasma (Innovative Research, cat \# IPLAWBK2E50ML) was processed as three separate samples $(1 \mathrm{ml}$ each). Each of the three replicate samples underwent IP-MS using the identical protocol that was used for the prospective clinical samples in this study. 